\title{
Teachers' dilemma bog down CLT in EFL contexts: A discussion on EFL teachers' beliefs and sources
}

\author{
Abdul Karim ${ }^{1}$, Abdul Rashid Mohamed ${ }^{2}$, Mohammad Mosiur Rahman ${ }^{3}$, Md. \\ Hamidul Haque ${ }^{4}$ \\ ${ }^{1}$ (School of Educational Studies, Universiti Sains Malaysia, Malaysia) \\ 2 (School of Educational Studies, Universiti Sains Malaysia, Malaysia) \\ ${ }^{3}$ (School of Language, Literacy and Translation Studies, Universiti Sains Malaysia, Malaysia) \\ ${ }^{4}$ (Department of English, American International University-Bangladesh)
}

\begin{abstract}
This article has penetrated the constraints derived from beliefs of teachers, and how they drive Communicative Language Teaching (CLT) not to be implemented properly in Bangladesh. Numerous studies conducted earlier investigated and revealed the issues affecting the successful implementation of CLT. This article exclusively investigates on the beliefs held by teachers and sources of those beliefs with its wider exploration. Examining such phenomenon in other EFL contexts, this study intends to find out the similarities of problem in terms of belief and sort out strategies adapted there to reshape beliefs of the teachers. Besides, this article also uncovers the problematic sources of EFL teachers' belief. The qualitative method is followed to complete the investigation. It is found that most of the teachers are cognizant about what CLT supposes them to do. Due to some barriers generated from the setting and their reluctance, CLT is not implemented properly. Therefore, contradictory stance of the teachers drastically affects the classroom practice following CLT. Finally, it is revealed that beliefs generated from teachers' own experience as language learners, experience of what works best and principles derived from an approach or method persuade teachers to perceive CLT with a bunch of wrong connotations.
\end{abstract}

Keywords- ELT, EFL, CLT, Teacher, Beliefs

\section{INTRODUCTION}

With its influential status in the global village, English invokes the teachers and learners to teach and learn it with volitional act to meet the requirements for successful communication in practical life, and consequently, introduction to the recent and feasible method for teaching English is necessitated by concern authorities in many Asian countries (Ullah, 2013). In Bangladesh, particularly, realizing the pedagogical downside are the teachers that orthodox approaches are underscoring solely the grammar and vocabulary which results in low achievement in English learning in this global and integrated platform, he stated. This phenomenon, according to him, leads to the paradigmatic shift from Grammar Translation Method (GTM) to Communicative Language Teaching (CLT) method initiated by Ministry of Education (MoE), Bangladesh in the field of English Language Teaching in late 1990s apprehending that conventional GTM slackened the learning process of English and indubitably led to the questionable achievement. GTM, in Bangladesh, initially possessed the popularity at its zenith; however, it failed to produce students' expected performance in real life communication due to its shortcomings (Ahmed, 2014). Therefore, to attain communicative ability, the policy was changed and the concentration was shifted from process-based learning following GTM to function-based method CLT, she stated.

The shift entails changes in both approaches of designing textbooks and teaching English. But, it is deplorable that in most cases, as Hosen (2015.) identified, the teachers or practitioners of such English as a Foreign Language (EFL) context were trained in GTM, though the curriculum policy endorsed CLT as the method for English language teaching and learning. According to him, although CLT possesses the hyperbolic impression, rarely does it seem to be effective in Bangladesh. The main reason for this is keeping teachers apart when designing the educational policy. Therefore, the feasibility of any method has lacked consideration from teachers' part. Traditionally, in Bangladesh, education policy has been determined by the donors rather than those with expertise (Hamid, 2010). Rahman (2010) identified education system as 'internal and external inefficiency', devoid of 'productivity... and clear-cut objectives... and policy directions', 'stagnant', 'inadequate', 'out-dated', 'limited', and one that 'produces graduates with no productive skills' (p. 5). Consequently, teachers' non-involvement in curriculum design and lack of training in CLT lead them to hold misconceptions that affect every sphere of CLT implementation. 


\section{CONTEXT OF THE STUDY}

GTM had been replaced by CLT in the higher secondary level in 2001 (Rahman, 2015) keeping the principle of it in mind that it will equip students with the communicative ability so that learners would perform linguistically when the situation requires. But CLT fails to achieve its expected goal. The reason for this is the influence of GTM on teachers prior to teaching. Abedin (2013), pertinently, claims that CLT is theoretically prevalent in Bangladeshi context but practical implementation in the name of CLT is the improvised version of CLT being influenced by GTM. Ahmed (2014) also explicates that despite prior optimism and striving from the Ministry of Education's part to uphold CLT, CLT failed to prompt learners' communicative ability due to different dominant issues. He corroborates that schools and colleges in Bangladesh prone to adopt conventional GTM.

The important factor that aggravates the teachers' belief is teachers' participation, as one of the stakeholders, are often overlooked when the policy and curriculum development are in the progress. Ali (2010b) found no collaboration existed among the stakeholders in different stages of curriculum development. Teachers, being unaware of the specific aims and objectives, are only asked to implement what curriculum plans to.

Mondal (2012) enunciated the fact that the gap between teachers and students in EFL setting resulted from teachers not being concerned about the authentic and fundamental needs of the learners. Teachers, he added, tend to teach following their own teaching technique, which leads to the detrimental outcome of the language programs. Chowdhury (2012) also admits that CLT in EFL contexts has been experiencing numerical impediments. This article, in particular, focuses on students' and teachers' beliefs regarding CLT.

\section{THE CURRENT SITUATION OF CLT IN BANGLADESH}

Ali and Walker (2014) delineate an inevitable outline which largely assures the successful implementation ELT in Bangladesh, and deplorably, this outline is partially absent the concurrent classroom practices in Bangladesh. Change in the syllabi along with the curriculum and new methodology cannot solely drive ELT being improved. Inadequacy in terms of training and support results in the teachers' perception being not to be changed. As a result, hardly do the teachers manage themselves to shift from teachers-fronted classroom to student fronted one. Consequently, conflict appears on their mind as new methodology, CLT, allows them to conduct student-centered class.

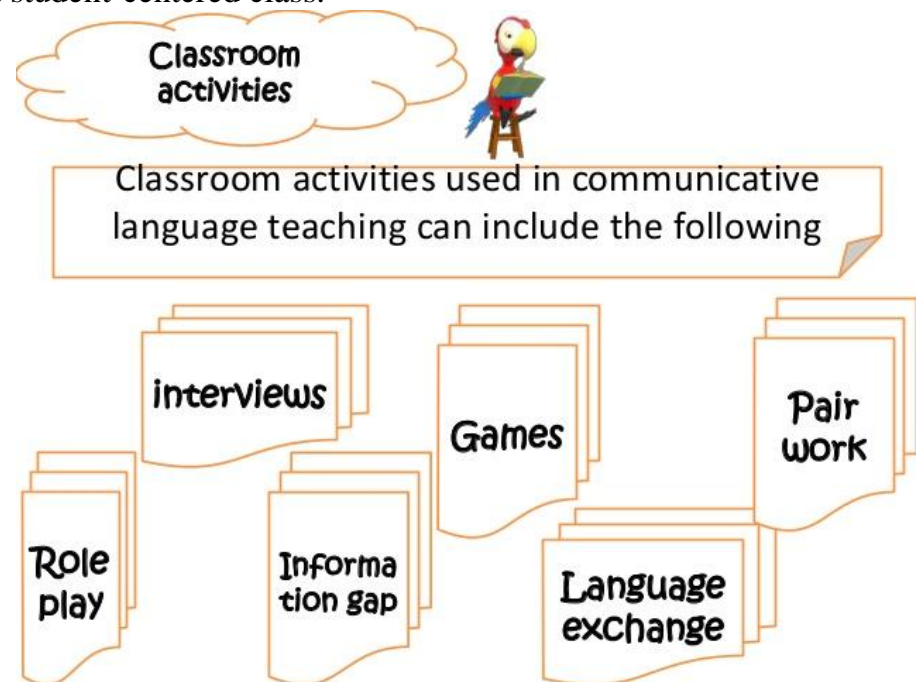

Diagram 1: CLT suggested classroom activities.

The activities in diagram 1 imply that performing such activities require a student-centered classroom. However, the position of CLT is not consolidated in Bangladesh. In particular, as Kirkwood and Rae (2011) identified, CLT fails to prompt students' communication by using English Language, although CLT claims to build students' communicative ability. In addition, Abedin, Mojlis and Akter (2010) alleged that the evidence of CLT is found solely in the written document- curriculum, but it is absent in the classroom practices. Teachers are yet to adopt CLT, and they are seemed to follow GTM (Abedin, 2012). Such acts let CLT slacken English language teaching and learning (Huda, 2013).

Haque (2014) and Ahmed (2014) found teachers and students responsible for aforementioned deterioration whereas, Ali and Walker (2014) identified problems with the CLT approach itself. There are problems with the materials which lead CLT to get lagged behind in Bangladesh. Ansary (2012) sorted out materials as one of the barriers to the successful implantation of it. For example, Ali (2012) discloses the mismatch between selected 
textbook "English for Today" for and aim of the curriculum. Therefore, along with the problematic belief of the teachers, such mismatch drives the deterioration in English teaching and learning in the higher secondary level.

\section{OBJECTIVES OF THE STUDY}

Studies conducted earlier on CLT, for the most, intended to identify the development in students' English proficiency in primary, secondary and higher secondary levels. Besides, a bunch of people also worked on revealing what do the teachers and students of these levels think about the classroom behavior and activities generated by CLT. This article, meticulously, sets out to discover the answer of the following question:

* How do the beliefs of teachers on CLT in Bangladesh get trivialized?

* What are the misconceptions existing in other EFL contexts?

* What are the sources of EFL teachers' misconceptions?

In this study, answering the first question considers critical insights of teachers' beliefs about CLT. This small scale study, therefore, examines the beliefs of their teachers about CLT. Apart from this, this study intends to explore misconceptions held by teachers in other EFL contexts where CLT is experiencing constraints, and reflects what has been done to remove those misconceptions.

\section{RATIONALE OF THE STUDY}

Teachers perceived as vehicles in the successful implementation of any curriculum plan possess beliefs, perception and expectation about CLT. The owned beliefs and perception can be either right or wrong (Chowdhury, 2012). Consequently, these influence on their classroom practice, he added. This is the reason why this article aims at scrutinizing the perception of teachers in EFL contexts to understand how their perception spells pedagogical dilemma. In addition, this study addresses the sources generating teachers' misconceptions. No other study conducted hitherto has focused on such extensive investigation. The findings thus supplement the material development process for teacher training programs.

\section{METHODOLOGY}

The strategy adopted to identify the varied perceptions of the teachers is qualitative method. It is chosen for several reasons. Firstly, the opinion of the teachers can be interpreted in words (Rahman, 2015). On top of this, as Bryman (2012) state, "Qualitative research is a research strategy that usually emphasizes words" (p. 380). In addition, qualitative method is chosen because it is effective to serve specific purposes of identifying unanticipated phenomena and influences Maxwell (1996, as cited in Tasnim, 2006). Data are collected from secondary sources. Hosts of researchers have been concentrated on secondary data analysis as a research methodology, e.g. Karim \& Rahman (2016); Rahman \& Pandian (2016), because of their significant insights. Teachers' feelings, opinions and experience about CLT constitute the data. These were gathered by using questionnaire, classroom observation, interview and so on, and are considered worth and reliable to fulfill the aim of the paper. To understand the concurrent thought of students and teachers, this paper collect data from the resources published between 2008 and 2017. Finally, this study compares the principles and classroom activities of CLT with those of teachers' perceived to understand how their thoughts impede the proper implementation of CLT.

\section{VII. $\quad$ FINDINGS AND DISCUSSIONS}

In this section, the beliefs of the teachers about CLT are presented and interpreted according to the underlying features of CLT. Such interpretations conspicuously portray how teachers' beliefs results in the trivialization of CLT.

\section{Ambiguity in CLT}

Not all the teachers in Bangladesh hold same opinion about CLT. Some believe that CLT is useful for students while others do not believe so. In addition, on one hand, teachers who believe CLT is useful do not implement this into their classroom practice, and on other hand, teachers who do not believe CLT as effective have not clear idea about CLT. For example, Ahmed (2016) figures out that CLT is a dubious term for the teachers. In contrast, Rahman's (2015) finding indicates teachers' satisfaction with CLT. They perceive CLT useful to learn faster, and become master in communication. They also admit that GTM is not compatible to be competent users of language as it does not integrate listening, speaking, reading and writing. Despite such belief, Rahman found that they conduct the class following GTM. Abedin (2013) also revealed the same phenomenon. The reason for this is the difficulty they experience while conducting communicative class. However, young teachers are more interested in CLT than their older counterparts. Hossen (2008) found that teachers do not perceive CLT method suitable to teach English language. Study carried out by by Afroze, Kabir, Rahman (2011, as cited in Rahman, n.d.) also divulges the idea of the teachers that CLT cannot be implemented 
effectively in Bangladeshi classrooms. They are seemed to be biased to GTM. Hossen (2008) uncovers that some teachers are eclectic, and they improvise classroom approach by combining GTM and CLT. Rahman (n.d.) also founds teachers doing same practice. According to them, CLT is time consuming as compared to GTM, and therefore, they perceive GTM more convenient. Parvin and Haider's (2012) findings also suggest the teachers' biasness to GTM in language teaching. The harm caused is the negative idea about CLT possessed by the teachers (Hossen, 2008). Even for the most, teachers are reluctant to acknowledge any new methods and techniques for language teaching.

\section{Teachers' understanding about the features of CLT}

It is found that all the teachers believe the following features belong to CLT: CLT put emphasis on fluency over accuracy, CLT pressurizes the teachers, CLT requires a lot of time to prepare class tasks, CLT is an ESL, not EFL approach, CLT is associated with communication carried out using second language (L2).

\section{Teachers' Perception regarding the activities}

Teachers, as Hossen (2008) mentioned, perceive role play, games, interviews, pair work as time consuming, and these mean nothing to attain a good result in the exam. Chowdhury (2012) identified, majority of the teachers corroborate CLT as it prescribes different activities to be carried out in the classroom. However, few seemed to be hesitant about the effectiveness of communicative activities in learning English. Very few teachers endorsed the communicative tasks stating that the repertoires required to perform practically are derived from these tasks. But in real life, they explained grammar deductively, though they endorsed the importance of communicative activities generated by CLT and their effect in the language learning. In addition, Rahman (n.d.) discloses the contradiction teachers hold in their mind. He founds teachers interested in applying CLT. But very few of them perform CLT techniques in their classes. Teachers' Talking Time (TTT) is more than Students' Talking Time (STT). Teachers are found underscoring reading and writing only. The activities done in the classroom, to a greater extent, do not comply with what CLT purports them to do (Hossen, 2008). Even the trained ones are reluctant to accelerate those activities because the teachers do not know the applying procedures of such activities in the classroom. Teachers seemed to emphasize on the topic and activities, which students will have to answer in the examination.

Littlewood (1981) enlivened the necessity of interaction in achieving communicative competence, which Hymes (1972) defined as the ability speaker needs to possess to communicate competently in an interactive session. Larsen-Freeman (2000) perceived interaction as a scaffold which prompts language learning. She opined that communication requires language, and thus in a communicative class, activities should be contrived concentrating on communication.

The paradoxical belief results in CLT not to be implemented in the classroom. For instance, study conducted by Raman and Malan (2014) reveals that all the participating teachers do not allocate equal time on 4 skills of language. They do not provide opportunity to make the class participatory. Thus, they mentioned, no pair work or group work has been introduced in the classroom. But, in the interview, teachers accord that CLT is effective and pertinent in EFL context like Bangladesh.

According to Littlewood (1981), CLT associates functional and structural aspects of language, and hence amalgamates these heading towards communicative attainment. Richards \& Rodgers (2001) elucidated that the more focus on communication than expertise on language forms results in diversified role of learners. Thus, Brown (2001) attributed, learners in a communicative class have to use the language both receptively and productively without any preparation like real life interactions.

\section{Teachers' Perception about group work and pair work}

Raman and Malan (2014) divulge that in terms of pair work and group work, all disputed the idea of exercising these in the classroom. Chowdhury (2012) also founds very few teachers practicing these in the classrooms. Haider and Chowdhury's (2012) study advocates this by eliciting that students rarely get engaged to pair and group activities. On the other hand, in CLT, "pair and group work" are emphasized because most of the activities are designed to be carried out in "pairs or small groups" (Richards, 2006, p. 20). In addition, according to Richards and Rodgers (2001), the compatible exercises adopted in CLT alleviate learners to achieve the communicative objectives of the curriculum, involve learners to participate in communication, and necessitate the use of information sharing, negotiation of meaning and interaction. Richards (2006) identified "information gap" as a significant feature of communication in CLT (p. 18). This results in real communication because, as Roy (2016) mentioned, generally, people communicate only for the information they do not know. Littlewood (1981), in addition, sectionalized the activities of learners in CLT into two parts- pre-communicative activities and "communicative activities. According to him, pre-communicative activities are the scaffold and communicative activities are the finisher. 


\section{Teachers' Perception about Grammar teaching in the classroom}

Chowdhury (2012) developed open-ended questions for the teachers so that the pragmatic responses would be divulged. In reply to the question related to the techniques adopted to teach grammar in the class, $80 \%$ of the teachers told that they were following deductive method to teach grammar. Most of the teachers stated that they first explain the grammatical rules. Then, they exemplify by writing sentences on the board. Very few are found teaching grammar by explaining rules and making stories. Raman and Malan (2014) also found that all the teachers focus on grammar and translation in the classroom. Rahman (n.d.) founds teachers acting as a kind of partial to the deductive teaching of grammar. They believe that knowledge of grammar helps learners to produce correct sentences. Haider and Chowdhury (2012) observe teachers teaching grammatical rules and structures explicitly. Explicit teaching of grammar, however, according to CLT, is prohibited in the classroom.Explicit teaching of grammar is absent in classroom conducted following CLT principles. Underlying principle for communication lies on the three different task types: for the first, activities that entail practical communication to boost learning (Richards \& Rodgers, 2001); secondly, activities that require the use of language to flourish learning (Johnson, 1982); and finally, meaningful language thrives the learning process (Richards \& Rodgers, 2001). Littlewood (1981) differentiated between "functional communication activities" and social interaction activities, neither of which contains contents related to the explicit teaching of grammar. Therefore, in no way, CLT concentrates on grammar.

\section{Teachers' perception regarding their role in the classroom}

Haider and Chowdhury's (2012) identify teachers supporting autonomy in the classroom as it provides them with command over students' learning. Teachers are seemed correcting students' errors instantly. They rationalized this by saying that learners prone to get derailed from the tasks they suppose to perform, and therefore to preclude this, teachers' interfere is necessary. In addition, students sometimes do not find the exact word. In these circumstances, with linguistic support teacher can interfere to enhance students' spontaneity and confidence, they added. Teachers are also seen correcting the students' mistake immediately. They, according to Chowdhury (2012), perceive correction as a pre-requisite to learning language. However, principles of CLT summons the avoidance of error at the beginning level of learning because it might constrain the fluency of the learners and lead to the teacher-fronted classroom. Besides, Richards (2006) stated, "The role of the teacher in CLT is that of a facilitator, who creates a classroom climate conducive to language learning and provides opportunities for students to use and practise the language and to reflect on language use and language learning" (p. 23). Breen and Candlin (as cited in Richards and Rodgers, 1986) identified two main roles of the teachers. The first one is to engage students in the communication, and the second one is to be the part of the communicative activities in the classroom. Richards and Rodgers (1986) explicated, other roles assumed for teachers in CLT are "needs analyst, counselor, and group process manager" (p. 77). The teacher's role in CLT is "less dominant" than in a teacher-centered method (Larsen-Freeman, 2000, p. 129). According to Ahmed (2014), a teacher in CLT plays the role of the guide, and not an "all-knowing knowledge provider" (p. 3). Unfortunately, no teacher seemed to hold his opinion relevant to these.

\section{Teachers' comprehension about learners' role}

Chowdhury (2012) revealed, as teachers claimed, students' passiveness in the classroom. They claimed unanimously that students behave as the silent spectators and act and the receiver of knowledge. Although, $80 \%$ of the teachers attributes to the major fact that CLT is a learner-centered approach. However, one of the teachers illuminated that the role of the learners in the classroom is ambiguous.

\section{Teachers' response about the materials and assessment procedure used}

Chowdhury (2012) identified from the answers generated by teachers that that due to the communicative activities either being not tantalizing or inadequate, students' participation is worthless. Similarly, dearth of authentic materials, as Hosen (n.d.) alleges, is a major constraint for the effective implementation of CLT. Chowdhury (2012) found the teachers accounting the students' 'goal to achieve certificate' through rote-learning method. Furthermore, assessment procedures of students' performance examination - lack motivational factors that can drive students toward English learning activities. Another teacher ascribed this debilitating participation to the large class size. Given students active participation is possible if teachers can assure effective and proper involvement of the learners to the activities, another teacher elicited.

\section{Insights of other EFL contexts}

The perception of CLT does not solely affect's its implementation in Bangladesh, but it also causes inconvenience to other EFL contexts. Hiep (2007) and Kumaravadivelu (2006) stated that CLT has a wider use around the globe since its introduction; however, controversies regarding this in the EFL contexts, particularly 
the Asian ones, cannot be denied. It is evident that problem rose usually from the perception of learners and teachers. Students' lack of enthusiasm to be apt in communication (Li, 1998) and teachers' perceived dilemma regarding the effectiveness of the pedagogical implementation of CLT principles (Coskun, 2011) are identified responsible for all problems associated with CLT. Like Bangladesh, discrepancies prevailed everywhere regarding what teachers or students believe and what they are practicing in real life. For example, Nishinto's (2008) study indicated that teachers in Japan hold the clear view about CLT; however, they expressed uncertainty regarding its implementation. English teachers see their central role in the classrooms to facilitate interaction, provide materials and act as part of interaction. But in real setting, it was found that the frequency of introducing group or pair activities is not satisfactory. There is also difference between curriculum directed practice and assessment system which is experienced in Bangladesh as well. Taguchi (2005) revealed teachers' biasness towards traditional methods of classroom drilling as they intend to prepare learners for entrance examinations. There is no question in that examinations requiring communicative ability. Therefore, teachers do not feel it important to initiate communicative activities. Affected by the same problem, teachers in Bangladesh tend to follow conventional GTM instead of CLT. Mak's (2011) study revealed that teachers perceive that their main duty is to deliver knowledge to the learners. If they focus more on interaction, they might fail to cover all the content. Therefore, eliciting students' response interests teachers less. Like those of Bangladesh, teachers in EFL contexts believe the upheaval of their dominance in the classroom. But concurrent methodology adopted in such contexts drives classroom from teacher-fronted one to student-centered one. There is no denying fact that such shift tensions the EFL teachers. The existing gap between students' role and classroom interaction leads teachers to perceive them as the only source of knowledge. Autonomy in the classroom is seemed to be possessed by the teachers. Mak founds that preconceived belief of the teachers constrains student-student and teacher-students interaction. Similarly, Bangladeshi teachers, to whom GTM has been concerning a lot for decades, become reluctant to incorporate CLT in their classroom practice. In addition, Rahimi and Naderi (2014) found that Iranian English teacher also have clear understanding of CLT; however they claim that the method itself is associated with problem. They, like Bangladeshi ones, feel that CLT does not suit Asian contexts since the assigned role of the teachers by CLT is not favorable to them. Kalanzadeh, Mirchenari, Bakhtiarvand (2013) also divulge problems lead CLT in Iranian context not to be implemented resulted from teachers misconception about CLT. Majority of the teachers perceive them deficient in terms of spoken English, and they believe without having good command, it becomes difficult to leverage CLT. Surprisingly, for most of the teachers, proficiency in spoken English refers to attaining appropriateness and fluency whereas; CLT itself neglects accuracy by eliminating teaching of forms. Students at the same time found not to be interested in communication. Teachers also seem to feel lagged behind in terms of insufficient strategic and sociolinguistic competence of using English in real life which they believe, lead them to disorient CLT in the classroom.

\section{Categorical presentation of the fundamental sources of EFL teachers' misconceptions}

Richards and Lockhart (1994) explicated that teachers' beliefs have been developed gradually over time. They identified teachers' beliefs consisted of subjective and objective dimensions. According to them, some beliefs may be fairly simple whereas, others are too complex to express. For example, determining the effective approach for teaching is one of such belief directed act, and thus, EFL teachers are yet to struggle to adopt CLT because the belief they have about it is ominous. Teachers' beliefs precede much of teachers' decision making and action. If teachers' beliefs are problematic, they will slacken learning. Kindsvatter, Willen and Ishler (1998) outlined some sources of teachers' belief. Categorizing these sources, the beliefs of teachers about CLT are discussed to understand where these misconceptions are originated from.

Teachers' own experience as language learnersAll the teachers being students hitherto have learning experience, and hence, their classroom acts are highly influenced by the way they taught. In EFL context like, Bangladesh where teachers were taught following GTM, and even they are trained following a general curriculum with no specific focus on CLT (see Malek et al., 2009; Obaidul Hamid, 2010; Ali \& Walker, 2014), naturally, beliefs of the teachers are bound to be ingrained with contradictory stuffs as aforementioned. Hassan (2013) also mentions that the deductive GTM only guides students to perform well in the examination. Consequently, relatively less emphasis has been given on practicing CLT.

Experience of what works best

For many teachers, experience precedes initial beliefs about teaching, and thus, effectiveness of teaching strategies varies from person to person (Kindsvatter et al., 1998). It is evident that English teachers, by and large, perceive CLT as less effective for EFL contexts because they have been practicing GTM for decades, and therefore, they are reluctant to integrate CLT in their classroom (for more see Coskun, 2011; Nishinto, 2008; Rahimi \& Naderi, 2014; Mak, 2011). They believe that students do well in the examination if they are taught following GTM. That is why the teachers are kind of biased to GTM. Teachers seemed to focus solely on reading and writing skills solely. They are rarely concern about students' communicative ability. Such incongruent belief rooted from practicing GTM over a long period of time relegates CLT. 
Principles derived from an approach or method

Teachers have the tendency to consistently practice a particular approach contending that it would be effective for conducting the class (Kindsvatter et al., 1998). Similarly, as mentioned above, although curriculum directs CLT, teachers tend to retain GTM which they have been following for a long time. That is how this source creates controversy and downplays CLT.

\section{CONCLUSION}

The findings of this study are of three types: misconceptions of Bangladeshi English teachers, misconceptions of the teachers in other EFL contexts and the specific sources of misconceptions carried by those teachers.

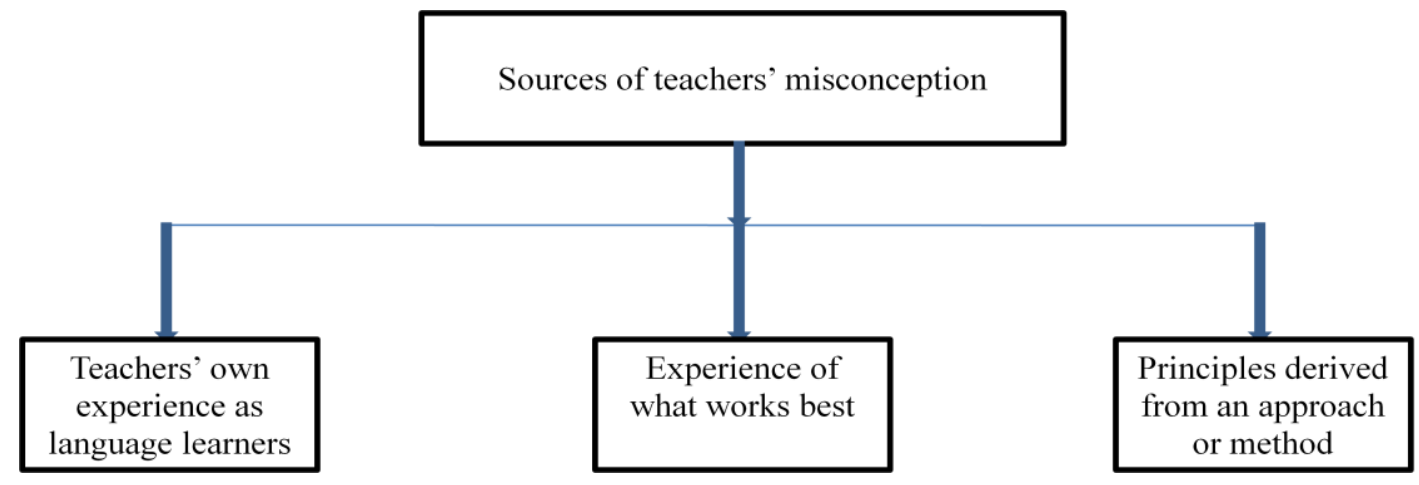

Figure 2: Source of EFL teachers' misconception

The areas identified will help the concern authorities to address these issues during the training program so that EFL teachers can reshape their thoughts. Coupled with this, the initiatives taken by other countries to remove beliefs ingrained with contradiction are presented which can help to reshape English teachers' belief not only in Bangladesh, but also in other EFL contexts where such problem exists. For instance, Kalanzadeh, Mirchenari, Bakhtiarvand (2013) identified teachers in Iran claiming lack of training in CLT responsible for low achievement. Therefore, to equip teachers with necessitated skills and expertise and to remove dilemma, they recommend feasible change in EFL methods courses. Bangladesh can incorporate such change by shifting to practical aspects rather than theoretical parts, as Hewing (2001):161) suggests the integration of demonstration instead of lecture in teacher education program. This will facilitate a hands-on expertise to the teachers. English teachers' education programs should be revised to a larger extent. It is evident that no separate training is provided for Bangladeshi English teachers, and they are being trained following a general teacher education curriculum Islam (2003, as cited in Ali \& Walker 2014), and they identified the training arranged for primary and secondary teachers as inadequate. This curriculum has no focus on CLT. To revitalize the programs the identified discrepancies of the teachers regarding perceived theory and practical use should be addressed. The data elicited clarify that there teachers are bewildered by CLT. Ahmed (2014) suggests that the teachers should be informed about the communicative principles so that they can implement them without compromise. For this, Ansarey (2012) emphasizes on the extensive CLT training for English teachers. Abedin (2013) also endorses this by stating that logistic supports like, teachers' training, teaching materials should be enriched so that they can be familiarized with new approaches of teaching. Rahman (2015) also calls for supervising the teachers adequately to observe whether they are adapting CLT into the classroom practices what they have learned during the training programs. He also urges Ministry of Education (MoE) to introduce CELTA (Certificate in English Language Teaching to Adults) training in order to retrieving CLT in a full swing. Addressing the sources of misconceptions, such program can reshape EFL teachers' thoughts what they have been exhibiting for decades. Similarly, Ali and walker (2014) argued for equipping teachers with the required knowledge and skills by building or rebuilding what Harmer (2003) calls their 'make-up'. This is how authorities can preclude the overlapping of GTM and CLT which usually results from teachers' eclectic attitude in the classroom.

\section{REFERENCES}

[1] Abedin, M. M., Majlish, S. H. K., \& Akter, S. (2010). Listening skill at tertiary level: A reflection. Dhaka University Journal of Linguistics, 2(3), 69-90.

[2] Abedin, M. M. (2013). The present mode of teaching in the ELT classes at the Higher Secondary level in Bangladesh: Is it the practice of CLT or disguised GTM?. Stamford Journal of English, 7, 1-15.

[3] Ahmed, M. K. (2016). Communicative Language Teaching: A Practical Scenario in the Context of Bangladesh. Advances in Language and Literary Studies, 7(5), 97-104. 
[4] Ahmed, S. (2014). The Communicative Language Teaching (CLT) at the Higher Secondary Levels in Bangladesh: Problems and Prospects from Teachers' Perspective. Language in India, 14(7).

[5] Ali, M. M. (2012). Revisiting English Language Teaching (ELT) Curriculum Design: How Appropriate is Bangladesh Higher Secondary Level National ELT Curriculum as a Learner-Centred One?. IIUC Studies, 7, 283-296.

[6] Ali, M., \& Walker, A. L. (2014). 'Bogged down'ELT in Bangladesh: Problems and policy. English Today, 30(02), 33-38.

[7] Ali, M. M. (2014). The study of errors and feedback in Second Language Acquisition (SLA) research: Strategies used by the ELT practitioners in Bangladesh to address the errors their students make in learning English. IIUC Studies, 8, 131-140.

[8] Ansarey, D. (2012). Communicative language teaching in EFL contexts: Teachers attitude and perception in Bangladesh. ASA University Review, 6(1), 61-78.

[9] Asassfeh, S., Khwaileh, F., Al-Shaboul, Y., \& Alshboul, S. S. (2012). Communicative language teaching in an EFL context: Learners' attitudes and perceived implementation. Journal of Language Teaching and Research, 3(3), 525-535.

[10] Brown, H. D. (2001). Teaching by principles. An interactive approach to language pedagogy. New York: AW Longman.

[11] Bryman, A. (2012). Social Resaerch Methods. New York: Oxford University Press.

[12] Chowdhury, K. B. (2012). Communicative Language Teaching Approach at Higher Secondary Level in Bangladesh-Teachers' Perceptions and Classroom Practice. Language in India, 12(2).

[13] Chowdhury, R., \& Kabir, A. H. (2014). Language wars: English education policy and practice in Bangladesh. Multilingual Education, 4(1), 21.

[14] Haque, M. F. (2014). Problems of CLT Approach with the Teachers and Students of Bangladesh.

[15] Haider, M. Z., \& Chowdhury, T. A. (2012). Repositioning of CLT from Curriculum to Classroom: A Review of the English Language Instructions at Bangladeshi Secondary Schools. International Journal of English Linguistics, 2(4), 12.

[16] Harmer, J. (2003). Popular Culture, Methods, and Context. ELT journal, 57(3), 288-94.

[17] Hewing, A. (2000). Innovation in English Language Teaching. London: Macquarie and the Open University.

[18] Hassan, M. K. (2013). Teachers' and students' perceived difficulties in implementing communicative language teaching in Bangladesh: a critical study (Doctoral dissertation, Open University).

[19] HOSEN, M. A. A HISTORICAL OVERVIEW OF COMMUNICATIVE LANGUAGE TEACHING IN BANGLADESH: PROBLEMS, PREJUDICES AND RESOLUTIONS. International Journal of English and Literature (IJEL), 1(5), 91-104.

[20] Hossen, M. T. (2008). Communicative language teaching: teachers' perception in Bangladesh (secondary level) (Masters dissertation, BRAC University).

[21] Hymes, D. (1972). On communicative competence in Sociolinguistics (Pride \& Pholmes, Eds.). Harmoundsworth, UK: Penguin.

[22] Emdadul Huda, M. (2013). Post-Method Pedagogy and ELT in Bangladesh. Global Journal of HumanSocial Science Research, 13(7).

[23] Johnson, K. (1982). Communicative syllabus design and methodology. Pergamon.

[24] Karim, A., \& Rahman, M. M. (2016). Revisiting the Content-Based Instruction in Language Teaching in relation with CLIL: Implementation and Outcome. International Journal of Applied Linguistics and English Literature, 5(7), 254-264.

[25] Kalanzadeh, G. A., Mirchenari, N. A., \& Bakhtiarvand, M. (2013). Perceived problems in using communicative language teaching (CLT) by EFL Iranian teachers. The International Journal of Language Learning and Applied Linguistics World, 2(3), 5-16.

[26] Kindsvatter, R., Willen, W., \& Ishler, M. (1988). Dynamics of effective teaching. New York: Longman.

[27] Kirkwood, A. T., \& Rae, J. (2011). A framework for evaluating qualitative changes in learners' experience and engagement: developing communicative English teaching and learning in Bangladesh. Evaluation \& Research in Education, 24(3), 203-216.

[28] Larsen-Freeman, D. (2000). Techniques and principles in language teaching (Second ed.). (R. N. Campbell, \& W. E. Rutherford, Eds.). New York: Oxford Univeristy Press.

[29] Littlewood, W. (1981). Communicative language teaching: An introduction. Cambridge University Press.

[30] Mak, S. H. Y. (2011). Tensions between conflicting beliefs of an EFL teacher in teaching practice. RELC Journal, 42(1), 53-67.

[31] Nishino, T. (2008). Japanese secondary school teachers' beliefs and practices regarding communicative language teaching: An exploratory survey. Jalt Journal, 30(1), 27. 
[32] Obaidul Hamid, M. (2010). Globalisation, English for everyone and English teacher capacity: Language policy discourses and realities in Bangladesh. Current Issues in Language Planning, 11(4), 289-310.

[33] Parvin, R., \& Haider, M. Z. (2012). Methods and practices of English language teaching in Bangla and English medium schools. Bangladesh Education Journal, 11(1), 51-63.

[34] Rahimi, M., \& Naderi, F. (2014). The relationship between EFL teachers' attitudes towards CLT and perceived difficulties of implementing CLT in language classes. International Journal of Applied Linguistics and English Literature, 3(3), 237-245.

[35] Rahman, M. (2009). Improving the relevance of humanities higher education in Bangladesh (Doctoral dissertation, Monash University. Faculty of Education. Education).

[36] Rahman, M. M., \& Malan, K. (2014). An Exploratory Study into Factors Affecting Achievement in English among Bangladeshi College Students: An Investigation of Teachers and Students Perceptions. Language in India, 14(6).

[37] Rahman, M. S. (2015). Implementing CLT at Higher Secondary Level in Bangladesh: A Review of Change Management. Journal of Education and Practice, 6(2), 93-102.

[38] Rahman, M. (2015). Teaching English at HSC Level in Bangladesh: An Empirical Appraisal. ASA University Review, 9(1).

[39] Rahman, M. S. (2015). DO TEACHERS AND STUDENTS WANT CLT? A STUDY OF BANGLADESHI COLLEGE TEACHERS'AND STUDENTS'PERCEPTION OF CLT.

[40] Rahman, M. M., \& Pandian, A. (2016). The Gap between Research and Practice in the Field of SLA: The Rationale behind It and Bridging the Gap. Journal of Applied Linguistics and Language Research, 3(3), 162-172.

[41] Rahaman, M. M. A. English Teachers' Perception of Communicative Language Teaching at the Secondary Level.

[42] Richards, J. C., \& Lockhart, C. (1994). Reflective teaching in second language classrooms. Cambridge University Press.

[43] Richards, J. C. (2006). Communicative language teaching today. New York: Cambridge University Press.

[44] Richards, J. C., \& Rodgers, T. S. (1986). Approaches and methods in language teaching. Cambridge: Cambridge University Press.

[45] Richards, J.C., \& Rodgers, T.R. (2001). Approaches and Methods in Language Teaching. Cambridge: Cambridge University Press.

[46] Roy, S. (2016). Challenges to Implementing Communicative Language Teaching (CLT) in Bangladesh. Language in India, 16(3).

[47] Sultana, M. A. (2014). Communicative approach in ESL classroom at the secondary level. Language in India, 14(6),pp.1-17.

[48] Ullah, M. M. (2016). CLT at the Higher Secondary Level in Bangladesh: Theory and practice. IIUC Studies, 12, 71-86.

[49] Taguchi, N. (2005). The communicative approach in Japanese secondary schools: Teachers' perceptions and practice. The Language Teacher, 29(3), 3-12.

[50] Tasnim, S. (2006). Job Satisfaction among Female Teachers: A study on primary schools in Bangladesh (Master's thesis, The University of Bergen). 